\title{
Spontaneous pneumothorax in an infant: an unusual complication of pertussis
}

\author{
Deepanjan Bhattacharya, Yogish Kumar Sharma, Jayashree Muralidharan, \\ Joseph L Mathew
}

Advanced Pediatrics Centre, Postgraduate Institute of Medical Education and Research, Chandigarh, India

Correspondence to Professor Joseph L Mathew, dr.joseph.I.mathew@gmail.com

Accepted 7 September 2019

D Check for updates

C) BMJ Publishing Group Limited 2019. No commercial re-use. See rights and permissions. Published by BMJ.

To cite: Bhattacharya $D$, Sharma YK, Muralidharan J, et al. BMJ Case Rep 2019;12:e231878 doi:10.1136/bcr-2019231878

\section{DESCRIPTION}

A 6-week-old girl presented with non-paroxysmal cough for 2 weeks, and rapid breathing for the past 5 days. It was associated with occasional post-tussive vomiting but not fever or poor feeding.

On examination, she had tachypnoea with tracheal deviation to the left and decreased breath sounds on the right side of the chest, with hyper-resonance on percussion. Chest X-ray suggested rightsided pneumothorax with contralateral mediastinal shift (figure 1A). Blood gas analysis showed respiratory acidosis ( $\mathrm{pH}$ 7.117, $\mathrm{paCO}_{2} 58.4 \mathrm{mmHg}$, $\mathrm{paO}_{2} 78.4 \mathrm{mmHg}$ ). She was administered oxygen by nasal prongs, and an intercostal drainage tube (ICDT) was inserted in the right second intercostal space (figure 1B). Following this, there was improvement in the clnical status and acidosis $(\mathrm{pH}$ 7.367, $\mathrm{paCO}_{2} 36.7, \mathrm{paO}_{2}$ 116.7).

Haemogram showed leucocytosis (total leucocyte count: $55.34 \times 10^{9} / \mathrm{L}$ ), and normal renal and liver function tests. Blood culture was sterile. PCR of the nasopharyngeal swab was positive for Bordetella pertussis, and oral azithromycin was given for 5 days. ICDT was removed by day 4 of hospitalization, and she was taken off oxygen by day 7 . Repeat chest X-ray showed resolution of pneumothorax, and she was discharged in haemodynamically stable condition.

Pertussis or whooping cough is caused by $B$. pertussis and is often a severe illness in infancy. It is usually characterised by cough of more than 2 weeks' duration, which is usually paroxysmal with
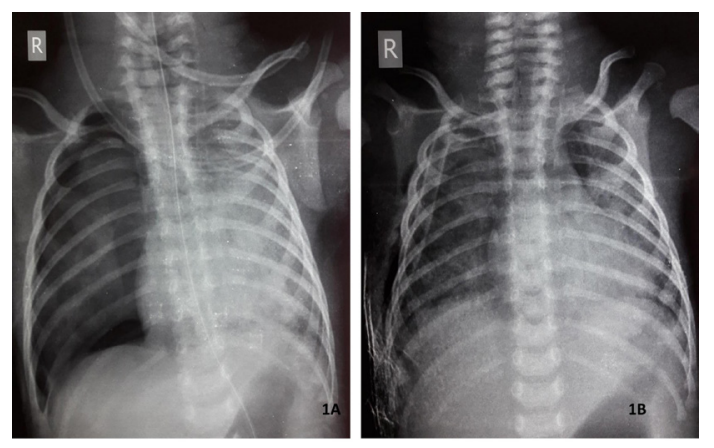

Figure 1 Serial chest $X$-rays showing right pneumothorax $(A)$ and resolution after insertion of intercostal drainage tube (B). post-tussive vomiting. In infants less than 3 months of age, apnoea and cyanosis may be additional features.

Rhinehart ${ }^{1}$ reported a 34-year-old woman with pertussis with features of right-sided pneumothorax on clinical examination, confirmed on skiagraphy. It was concluded that it was a spontaneous rupture of a pre-existing pleural bleb of the right lung secondary to strain during paroxysmal coughing. Nicolai et $a l^{2}$ analysed 19 infants with PCR-positive pertussis (median age 72 days), of whom $3(15.8 \%)$ had respiratory complication in the form of pneumothorax.

Pneumothorax is a rarely reported complication of pertussis and is usually secondary to increased intrathoracic pressure during paroxysmal coughing. In our case, there were subtle clues, such as prolonged cough for more than 2 weeks and leucocytosis, and pertussis was confirmed by PCR.

\section{Learning points}

- Spontaneous pneumothorax in children is extremely rare.

- Pertussis should always be considered as a differential in an infant with prolonged cough and marked leucocytosis.

- Spontaneous pneumothorax is an underreported complication of pertussis and is secondary to paroxysmal coughing.

Contributors DB, YKS: patient management, literature review and preparation of the initial draft of the manuscript. JM: critical review of the manuscript for important intellectual content and fina approval of the version to be published. JLM: clinician-in-charge, critical review of the manuscript for important intellectual content and final approval of the version to be published.

Funding The authors have not declared a specific grant for this research from any funding agency in the public, commercial or not-for-profit sectors.

Competing interests None declared.

Patient consent for publication Parental/guardian consent obtained.

Provenance and peer review Not commissioned; externally peer reviewed.

\section{REFERENCES}

1 Rhinehart BA. Spontaneous Pneumothorax: Report of a Case Apparently Following Whooping-Cough. Radiology 1926;7:253-4.

2 Nicolai A, Nenna R, Stefanelli P, et al. Bordetella pertussis in infants hospitalized for acute respiratory symptoms remains a concern. $B M C$ Infect Dis 2013;13:526. 
Copyright 2019 BMJ Publishing Group. All rights reserved. For permission to reuse any of this content visit https://www.bmj.com/company/products-services/rights-and-licensing/permissions/

BMJ Case Report Fellows may re-use this article for personal use and teaching without any further permission.

Become a Fellow of BMJ Case Reports today and you can:

- Submit as many cases as you like

Enjoy fast sympathetic peer review and rapid publication of accepted articles

Access all the published articles

Re-use any of the published material for personal use and teaching without further permission

Customer Service

If you have any further queries about your subscription, please contact our customer services team on +44 (0) 2071111105 or via email at support@bmj.com.

Visit casereports.bmj.com for more articles like this and to become a Fellow 